\title{
The effect of different chelating agents on the push-out bond strength of proroot mta and endosequence root repair material
}

\section{Purpose}

This study aimed to evaluate the effects of $17 \%$ ethylenediaminetetraacetic acid (EDTA), 7\% maleic acid (MA), and 10\% citric acid (CA) on the push-out bond strength of ProRooT MTA and Endosequence Root Repair Material (ERRM) putty.

\section{Materials and Methods}

Eighty single-rooted extracted human teeth were instrumented to obtain a standardized immature teeth model. Based on the chelating agents tested, the specimens were randomly divided into three experimental groups: Group 1 (17\% EDTA), Group 2 (7\% MA), Group 3 (10\% CA), and Group 4 (Positive Control) $(n=20$ for each group). Each group was further classified into two subgroups: Group A (ProRoot MTA) and Group B (Endosequence Root Repair Material (ERRM) putty) ( $n=10$ for each subgroup). After irrigation and placement of cements, teeth were stored at $37^{\circ} \mathrm{C}$ and in $100 \%$ humidity for a week. A total of 240 dentine discs (three discs per teeth) were obtained and subjected to push-out assay. Data was analyzed using two-way analysis of variance and Tukey's post hoc t-test.

\section{Results}

Both types of chelating agent and calcium silicate-based cement were significantly associated with the push-out bond strength values. The push-out bond strength was significantly less for CA as compared to EDTA or MA. ERRM had higher bond strength values than ProRoot MTA $(p<0.05)$.

\section{Conclusion}

The use of chelating agents increased the push-out bond strength of CSC. Regardless of tested chelating agents, ERRM had higher bond strength values than ProRoot MTA

Keywords: Calcium silicate-based cement; chelating agent; Endosequence Root Repair Material; push-out bond strength

\section{Introduction}

Calcium silicate-based cements (CSC) have a wide variety of applications in endodontic therapy (1). CSC should exhibit high bond strength and display resistance to displacement forces that may occur owing to functional consequences or placement of restorative materials (2). Displacement, leakage, and micro fractures can occur in CSC because of these forces (3). Therefore, evaluating the effect of different variables that influence the bond strength of CSC to dentin is important for clinical success.

The smear layer is a non-homogenous structure composed of microorganisms, blood cells, residual pulp, odontoblast extensions and dentin chips (4). As the smear layer can penetrate up to 40 microns into the dentin tubules, the ability of intracanal medicaments and CSC to penetrate dentin is reduced, thereby adversely affecting the bond

\author{
Burak Buldur' ${ }^{1}$, \\ Fatih Öznurhan' ${ }^{1}$ (D), \\ Arife Kaptan ${ }^{1}$ (D)
}

ORCID IDs of the authors: B.B. 0000-0003-4764-819X; F.O. 0000-0002-7797-0932; A.K. 0000-0003-4371-7768

'Sivas Cumhuriyet University, Faculty of Dentistry, Department of Pediatric Dentistry, Sivas, Turkey

Corresponding Author: Burak Buldur E-mail: bbuldur@gmail.com

Received: 02 March 2018 Revised: 25 October 2018 Accepted: 28 November 2018 DOI: 10.26650/eor.20191618 
strength (5). Chelating agents are used to remove the smear layer in root canal therapies. However, these agents cause demineralization and structural changes in root canal dentin, thus affecting the bond strength of endodontic materials to root canal dentin (6).

Ethylenediaminetetraacetic acid (EDTA) is a frequently used chelating agent in removing smear layer and stimulates cellular differentiation and tissue formation, and increases the release of growth factors throughout the root canal (7). However, EDTA can cause weakness of the dentin structure in immature teeth of young patients, as it causes erosion in the dentin tubules (8). Because EDTA interferes with the hydration of MTA, it decreases microhardness, bond strength and biocompatibility of MTA (9). As alternatives to EDTA, citric acid (CA) and maleic acid (MA) can be used in endodotic procedures (10). Both agents cause wider opening in the dentin tubules (11), and increase the bond strength, resulting in an increased contact area between root canal dentin and endodontic cement (12). MA is suggested as an alternative to EDTA. It is highly acidic, less toxic than EDTA and has a greater ability to remove the smear layer than EDTA (10). As MA is a slightly organic acid, it is recommended that MA should be used in root canal irrigation at a concentration range of $5-15 \%(10)$. CA, another chelating agent, is used in different concentrations (1-50\%) to remove the smear layer (13). CA, when used at a concentration of $1 \%$, also presents a smear layer-removal effect similar to EDTA (14). Silveiro et al. (15) reported that $10 \%$ CA was effective in removing the smear layer because its $\mathrm{pH}$ was close to the neutral $\mathrm{pH}$ and was therefore more biocompatible.

Although mineral trioxide aggregate (MTA) is frequently used with numerous applications in endodontics, it has several disadvantages such as staining of the teeth, difficulty in clinical use, and long setting time (16). Because of these disadvantages, researchers are attempting to overcome the limitations of MTA. Recently, Endosequence Root Repair Material (ERRM), a bioceramic material was produced to overcome the disadvantages of MTA (17). It has similar uses like that of MTA and is available in mix-free, ready-to-use paste or injectable pat forms.

Exposure to irrigation solutions during chemomechanical irrigation changes the chemical and mechanical properties of the root canal dentin surface and so evaluating the effect of chelating agents on the bond strength of CSC should be investigated. Therefore, the purpose of this study was to examine the effects of $17 \%$ EDTA, 7\% MA, and 10\% CA on the push-out bond strength of ProRooT MTA and ERRM. The null hypotheses tested were as follows: (1) the chelating agent has no effect on the push-out bond strength of ProRoot MTA and ERRM; and (2) there is no difference between the push-out bond strength values of ProRoot MTA and ERRM.

\section{Materials and Methods}

\section{Teeth Selection}

Ethical approval was obtained from the Health Ethics Committee of the University of Cumhuriyet, Sivas, Turkey (ID: 2016-12/08). Based on the data from a pilot study, the values used in the power analysis were based on the following: $a=0.05$, $\beta=0.10,1-\beta=0.90$. It was decided to take a sample of 80 teeth.
The present study was conducted on 80 single-rooted human teeth freshly extracted due to periodontal problems. The teeth were immersed in $\mathrm{NaOCl}$ (Wizard, Ankara, Turkey) for 3 hours and root surfaces were cleaned using a curette. Teeth were stored in $0.1 \%$ thymol solution at $4^{\circ} \mathrm{C}$ under the laboratory procedures. Multidimensional preoperative radiographs were taken to confirm the root curvature as less than $20^{\circ}$ and also to confirm the presence of a single, noncomplicated root canal.

\section{Specimen Preparation}

Each tooth was decoronated below the cementoenamel junction using diamond burs and the root lengths were standardized to $15 \pm 1 \mathrm{~mm}$. Working length (wl) was determined by inserting a no. $10 \mathrm{~K}$ file (Dentsply Maillefer, Ballaigues, Switzerland) into each root canal until apically visible and then subtracting one $\mathrm{mm}$ from this point. Each root canal was instrumented with nickel titanium rotary Protaper Next files (Dentsply Maillefer, Ballaigues, Switzerland) up to size F5. During each file change, $1 \mathrm{~mL}$ of $2.5 \% \mathrm{NaOCl}$ was applied with a side vented 27-gauge needle (Monoject, Tyco Healthcare, Mettawa, IL, USA) for $1 \mathrm{~min}$. To provide an immature tooth model with a standard intracanal diameter, Peeso reamers (Mani Inc, Tochigi, Japan) from \#1 to \#6 were used sequentially. Finally, a \#6 Peeso reamer protruded one $\mathrm{mm}$ beyond the apical foramen (3). Each root canal was irrigated with $5 \mathrm{ml}$ of $5.25 \% \mathrm{NaOCl}$ for $5 \mathrm{~min}$. Finally, all roots were irrigated with $15 \mathrm{~mL}$ of bidistilled water. The root canals were then dried with paper cones (Dentsply, Maillefer, Switzerland).

The specimens were randomly divided into three experimental groups according to the chelating agents tested: Group 1 (17\% EDTA (Wizard, Rehber Chemistry, Istanbul, Turkey)), Group 2 (7\% MA (Merck Schuchardt, OHG, Hohenburn, Germany)), Group 3 (10\% CA (Cumhuriyet University, Faculty of Medicine,Sivas, Turkey) and Group 4 (Positive Control) ( $n=20$ for each group). Each group was further classified into two subgroups with regard to the type of CSC tested: Group A (ProRoot MTA) and Group B (ERRM) ( $n=10$ for each group).

\section{Irrigation Procedure and Placement of Cements}

Each tooth was irrigated for $4 \mathrm{~min}$ and the total chelating agent volume delivered was $20 \mathrm{~mL}$ for each canal (18). Continuous irrigation was applied using a special irrigation device (VATEA, ReDent-Nova, Israel) that pumped the irrigants at the rate of $5 \mathrm{~mL} / \mathrm{min}$. Further, the chelating agents were removed by rinsing with $10 \mathrm{~mL}$ bidistilled water for 2 min. Approximately $4 \mathrm{~mm}$ of each type of cement tested (ProRoot MTA and ERRM) was placed in the coronal third of the root canals by using a MTA gun (MAP System, Dentsply Tulsa Dental, OK, USA) and compressed with hand plugs (Dentsply, Maillefer, Switzerland). ProRoot MTA was manually mixed using a metal spatula with a water to powder ratio of 0.33 following the manufacturer's recommendations. ERRM is premixed by the manufacturer. Each type of cement was gently applied to the dentinal walls with a moistened cotton pellet. The teeth were wrapped with a wet gauze and stored at $37^{\circ} \mathrm{C}$ and in $100 \%$ humidity for a week (2). 


\section{Push-Out Test}

The teeth were embedded in acrylic blocks prepared as apical thirds in acrylic. Parallel transverse sections were obtained with a water-cooled low-speed IsoMet diamond saw (Buehler, Lake Bluff, NY, USA) from the coronal to the apical direction (three slices per tooth) (3). A total of 240 dentin slices (approximately $1 \mathrm{~mm}$-thickness) were obtained. The thickness of each slice was measured using digital calipers (Teknikel, Istanbul, Turkey) with an accuracy of $0.001 \mathrm{~mm}$. The homogeneity of the groups in terms of slice thickness was confirmed through analysis of variance (ANOVA) ( $p>0.05)$.

A continuous load was applied to the center of the cements tested using a stainless steel cylindrical plunger of one $\mathrm{mm}$ in diameter, mounted onto a Lloyd LRX universal testing machine (Lloyd Instruments, Ltd., Fareham, UK). Loading was applied with a speed of $1 \mathrm{~mm} \mathrm{~min}-1$ from the apical to coronal direction until dislodgement of the cement occurred. All three slices of each teeth were tested using the push-out test and the mean was taken. The push-out bond strength was calculated in megapascals ( $\mathrm{MPa}$ ) by dividing the maximum load at failure $(\mathrm{N})$ by the area of surface adhesion using the formula (19), area $=2 \pi r \times h$ (where $\pi=3.14$, a constant value, $r=$ radius of intraradicular space, and $h=$ slice thickness in $\mathrm{mm})(20)$.

\section{Evaluation of Failure Patterns}

After the push-out test, the fracture surfaces of all specimens were examined with a stereomicroscope (Zeiss) under $25 \times$ magnification. Photographs of different fracture types of the specimens were obtained with a stereomicroscope-based photographic machine (Canon EOS 1000D, Canon, Inc., Tokyo, Japan). Each sample was classified into one of the following categories: (i) adhesive failure at cement/dentin interface; (ii) cohesive failure within cement, and (iii) mixed failure in both cement and dentin. One representative specimen for each group was examined for scanning electron microscopy (SEM) analysis. Each specimen was dehydrated in graded ethanol series $25 \%$, $50 \%, 75 \%, 90 \%$ for 25 min and finally in 100\% ethanol for $1 \mathrm{~h}$. The specimens were critically point-dried, mounted on aluminum stubs, sputter-coated with gold/palladium and examined with a scanning electron microscope (SEM) (Leo 440 CCD, Leica, Bensheim, Germany).

\section{Statistical Analysis}

Data was processed by SPSS for Windows, Version 22.0 (SPSS Inc., Chicago, IL, USA). The mean and standard deviation values of the push-out bond strength were calculated for each group. The effects of the type of chelating agents and endodontic cements on push-out bond strength were analyzed through two-way ANOVA and multiple comparisons were performed by Tukey's post- hoc test. A p-value less than 0.05 was considered statistically significant.

\section{Results}

Table 1 shows the mean values and standard deviations of the push-out bond strength (MPa). The use of chelating agents increased the push-out bond strength of endodontic cements. Both types of chelating agent and endodontic cement were significantly associated with the push-out bond strength values $(p<0.05)$. Regardless of the endodontic cements used, the push-out bond strength was significantly less for CA as compared to EDTA or MA $(p<0.05)$. There was no statistically significant difference between EDTA and MA ( $p>0.05)$. Regardless of the chelating agents tested, ERRM had higher bond strength values than ProRoot MTA $(\mathrm{p}<0.05)$.

Table 1 shows the distribution of the failure patterns. Adhesive failure was the failure pattern mostly observed in the CA group, whereas, cohesive and mixed failures were the failure pattern mostly observed in the EDTA and MA groups, respectively. Fig. 1 shows the representative stereomicroscope and SEM images of failure modes: (a) adhesive failure, (b) cohesive failure, and (c) mixed failure.

\section{Discussion}

Previous studies examined the effects of various variables on the bond strength of different $\operatorname{CSC}(2,3)$. These studies reported that the success of endodontic treatments was due to the well-adapted coronal restoration as well as the resistance of the repair agents to displacement forces generated during the condensation of permanent restorative materials. CSC are desired to show dislocation resistance to mechanical forces such as occlusion or condensation of restorative materials (2). It has been reported that the physical properties of endodontic cements change after root canal irrigation (21). Also, the removal of the smear layer causes a closer contact

Table 1. Push-out Bond Strength Values (MPa), and Distribution of Failure Modes for Each Group Groups

\begin{tabular}{|c|c|c|c|}
\hline \multirow[b]{2}{*}{ Chelating Agents } & \multicolumn{2}{|c|}{ Calcium Silicate-Based Cement } & \multirow{2}{*}{$\begin{array}{c}\text { Mode of Failure } \\
n(A / C / M)\end{array}$} \\
\hline & ProRoot MTA & Endosequence RRM & \\
\hline 17\% EDTA & $4.71 \pm 0.84^{\mathrm{a}}$ & $5.17 \pm 0.90^{\mathrm{a}^{*}}$ & $11 / 34 / 15$ \\
\hline 7\% Maleic Acid & $4.75 \pm 1.13^{\mathrm{a}}$ & $5.23 \pm 1.20^{\mathrm{a}, *}$ & $11 / 13 / 36$ \\
\hline $10 \%$ Citric Acid & $3.99 \pm 0.89^{b}$ & $4.50 \pm 0.86^{b_{1}^{*}}$ & $36 / 12 / 12$ \\
\hline Control (no agent) & $3.97 \pm 0.70^{b}$ & $4.23 \pm 0.81^{b}$ & $15 / 19 / 26$ \\
\hline
\end{tabular}



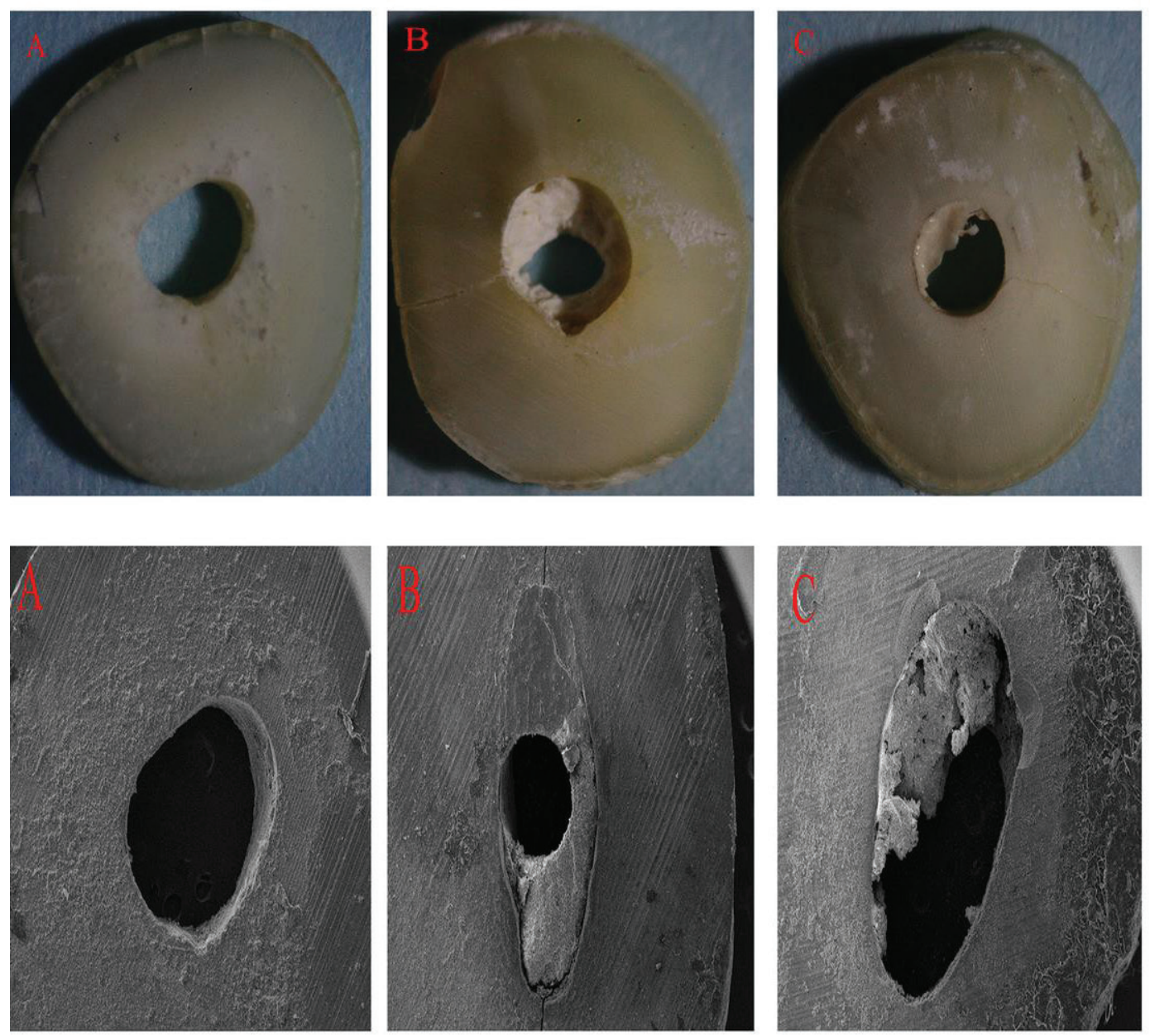

Figure 1. Representative stereomicroscope $\left(25^{\times}\right)$and scanning electron microscope (SEM) (54) images of failure modes; $(A)$ adhesive failure at cement/dentin interface; (B) cohesive failure within cement, and (C) mixed failure in both cement and dentin.

between the cement and root canal dentin which is required for optimal adhesion, as a result this allows chemical bonding or micromechanical interlocking.

There are several studies on the effects of various variables, such as the different types of cement, intracanal medicaments $(2,3)$, placement techniques of cement, and irrigation regimens (21) on the bond strength of CSC. However, there has been limited research focus on the effect of chelating agents on the bond strength of CSC. Based on this information, the effects of $17 \%$ EDTA, 7\% MA, and 10\% CA on bond strength of ProRooT MTA and ERRM were examined in the present study. Both null hypotheses of the study were rejected because both EDTA and MA increased the bond strength values of endodontic cements as compared to CA. In addition, ERRM was found to have higher bond strength values than ProRooT MTA.

There are several methods to test the bond strength (22). In this study, push-out bond strength test was used. This is a commonly used test to measure the bond strength in the root canal (22). Goracci et al. reported that the push-out test better reflects the clinical conditions of the fracture pattern than microshear or microtensile methods, and is more reliable than other tests (22). Not only were there numerous failures in the preparation of the samples in the microtensile test, the observed data in such tests were distributed over a wide range. On the contrary, the method used in our study allows testing of regional differences and reduces premature failure rates as compared to other tests (19).
Irrigation of root canals with chelating agents such as EDTA, MA or CA is recommended to effectively remove the smear layer, $(1,10,13,15)$. However, MA has been shown to be more biocompatible than $\operatorname{EDTA}(23)$, with a better smear layer-removal ability in sclerotic root canals (10). MA at a concentration of $7 \%$ was used in this study since higher concentrations may cause damage to intertubular dentin as reported previously (24). CA at a recommended concentration of $10 \%$ was used in this study. The decalcifying action of $10 \%$ CA was found to be double or more than that of $1 \%$ CA (15).

The results of the present study can be attributed to various factors. The first is the region where the discs were obtained. In the present study, dentin discs were obtained from the coronal third of the root canal. This is consistent with the study by Ballal et al. (10), in which the authors reported that one minute application of $7 \%$ MA was more effective than $17 \%$ EDTA in removing the smear layer in the apical third of the root canal system, but not in the middle and coronal third. In addition, no significant difference was found to exist between MA and EDTA with respect to the degree of microhardness as reported by Ballal et al. (25). In contrast, Ulusoy and Gorgul reported that MA had a higher reduction in dentine microhardness as compared to EDTA (26). In our study, the push-out bond strength was found to be significantly less for CA than for EDTA and MA $(p<0.05)$. This is consistent with a previous finding that CA was less effective than EDTA in removal of the smear layer (27). 
Secondly, the results of the present study can also be attributed to the irrigation procedure employed in our study. There is no definite protocol of the type or concentration of chelating agents. However, different irrigation solutions have been shown to affect the adhesion of materials to dentine surfaces as a result of the effect on dentinal walls which includes alteration of surface energy or wetting ability of dentinal walls. Consistent with this study, Ballal et al. (10) have reported the decreased surface tension of $17 \%$ EDTA compared to $7 \% \mathrm{MA}$, which may be a possible explanation for the higher bond strength of tested CSC in our study. In addition, while EDTA has been shown to cause complete demineralization of the root canal dentine, MA and CA generate mineral gradients (10). One reason for the lower bond strength values of CA groups may be because the decalcifying capacity of CA is time-dependent. Lopez et al. (28) reported that the amount of $\mathrm{Ca} 2$ extracted in the CA and EDTA solutions increased with longer immersion time. Consistent with the findings of the present study, Ballal et al. reported that MA is highly acidic and has a better demineralizing effect (25).

In this study, irrespective of the chelating agents tested, ERRM was found to have higher bond strength values than ProRooT MTA ( $p<0.05$ ). One of the reasons may be due to the physical and chemical properties of cements that were tested. The presence of zirconium oxide improved certain physical properties of bioceramics. The composition and particle size of existing cements affecte the interaction between cement and root canal dentin (21). ERRM has a smaller particle size than MTA. In addition, ERRM can form chemical bonds with root canal dentin walls, thus creating a robust connection. It was argued that the bioceramic cements when reacted with moisture, form hydroxyapatite that may chemically bond to the tooth structure (29). This may result in a $2 \%$ expansion because of the setting reaction, thus adapting better to the root canals. Because of crystal growth in dentin tubules, the effect of dentinal bridge formation can be strengthened, thereby increasing micromechanical involvement. Furthermore, the bond strength of ERRM may be higher than that of ProRooT MTA owing to the particle structure and hydrophilic properties of ERRM (30). Inconsistent with the present study, Shokohijenad et al. (31) reported that bond strength of MTA and ERRM paste was significantly lower in samples stored in conditions with an acidic $\mathrm{pH}$; however, the push-out bond strength of the ERRM putty was not influenced by acidity. However, while the samples were kept in an acidic medium for 4 days in their study, the total contact with the root surface of the chelating agents tested was limited to five minutes in our study, consistent with the recommended clinical use.

One limitation of the present study was that it was an in vitro study. Thus, it was not possible to fully reflect the oral environment (occlusal stresses, blood-saliva contamination, etc.). Therefore, further in vivo studies are needed to investigate the actual bond strength of the tested materials.

\section{Conclusion}

Within the limitations, it may be concluded that the use of chelating agents increased the push-out bond strength of CSC. Both of EDTA and MA increased the bond strength of CSC when compared to CA. ERRM had higher bond strength values than ProRooT MTA.
Türkçe öz: Proroot MTA ve endosequence kök tamir materyalinin bağlanma dayanımı üzerine farklı şelasyon ajanlarının etkisinin incelenmesi. Amaç: Bu çalışmada, ProRoot MTA ve Endosequence Kök Tamir Materyalinin (ERRM) push-out bağlanma dayanımı üzerine \%17 etilendiamin tetraasetik asit (EDTA), \% 7 maleik asit (MA) ve \%10 sitrik asitin (SA) etkilerinin değerlendirilmesi amaçlandı. Gereç ve Yöntem: Standardize edilmiş olgunlaşmamış bir diş modelini elde etmek için seksen adet tek köklü yeni çekilmiş insan dişleri prepare edildi. Test edilen şelasyon ajanlarına göre örnekler rastgele üç deney grubuna ayrıldı: Grup 1; (\% 17 EDTA), Grup 2; (\% 7 MA), Grup 3; (\% 10 SA) ve Grup 4; (Pozitif Kontrol) $(n=20)$. Her bir ana grup daha sonra iki alt gruba ayrıldı: Grup $A$; (ProRoot MTA) ve Grup B; ERRM $(n=10)$. Irrigasyon ve simanların yerleştirilmesinden sonra, dişler $37^{\circ} \mathrm{C}^{\prime}$ de ve $\% 100$ nemli ortamda bir hafta boyunca saklandı. Toplam 240 dentin diski (diş başına üç disk) alındı ve push-out bağlanma testi yapıldı. Elde edilen veriler, iki yönlü varyans analizi ve Tukey's post hoc $t$-testi kullanılarak analiz edildi ( $p=0.05$ ). Bulgular: Hem test edilen şelasyon ajanların hem de kalsiyum silikat bazlı simanların türü, push-out bağlanma dayanımı değerleri ile anlamlı derecede ilişkili bulundu ( $p<0.05)$. Push-out bağlanma dayanımı, EDTA veya MA'e kıyasla SA için anlamlı olarak daha az görüldü $(p<0.05)$. ERRM, ProRoot MTA'dan daha yüksek bağlanma dayanımı değerlerine sahipti $(p<0.05)$. Sonuç: Şelasyon ajanlarının kullanımı kalsiyum silikat simanlarının bağlanma dayanımını artırmıştır. Test edilen şelasyon ajanlarından bağımsız olarak, ERRM, ProRoot MTA'ya göre daha yüksek bağlanma dayanımı değerlerine sahip bulundu. Anahtar kelimeler: kalsiyum silikat siman; şelasyon ajanlarl; endosequence kök kanal tamir materyali; mineral trioksit agregat; bağlanma dayanımı

Ethics Committee Approval: Ethical approval was obtained from the Health Ethics Committee of the University of Cumhuriyet, Sivas, Turkey (ID: 2016-12/08).

Informed Consent: Informed consent was obtained from the participants.

Peer-review: Externally peer-reviewed.

Author contributions: $\mathrm{BB}, \mathrm{FO}$ and $\mathrm{AK}$ participated in designing the study. $\mathrm{BB}, \mathrm{FO}$ and $\mathrm{AK}$ participated in generating the data for the study. BB, FO and AK participated in gathering the data for the study. $\mathrm{BB}$ participated in the analysis of the data. $\mathrm{BB}$ wrote the majority of the original draft of the paper. BB, FO and AK participated in writing the paper. All authors approved the final version of this paper.

Conflict of Interest: The authors have no conflicts of interest to declare.

Financial Disclosure: This research project received no financial support.

\section{References}

1. Kishen A, Peters OA, Zehnder M, Diogenes AR, Nair MK. Advances in endodontics: Potential applications in clinical practice. J Conserv Dent 2016;19(3):199-206. [CrossRef]

2. Nagas E, Cehreli Z, Uyanik M, Vallittu P, Lassila L. Effect of several intracanal medicaments on the push-out bond strength of ProRoot MTA and Biodentine. Int Endod J 2016;49(2):184-8. [CrossRef]

3. Topçuoğlu HS, Arslan H, Akçay M, Saygili G, Çakici F, Topçuoğlu G.The effect of medicaments used in endodontic regeneration technique on the dislocation resistance of mineral trioxide aggregate to root canal dentin. J Endod 2014;40(12):2041-4. [CrossRef]

4. Şen B, Wesselink $P$, Türkün $M$. The smear layer: a phenomenon in root canal therapy. International Endodontic Journal 1995;28(3):141-8. [CrossRef]

5. Torabinejad M, Handysides R, Khademi AA, Bakland LK. Clinical implications of the smear layer in endodontics: a review. Oral Surg Oral Med Oral Pathol Oral Radiol Endod 2002;94(6):658-66. [CrossRef] 
6. Serper A, Çalt S. The demineralizing effects of EDTA at different concentrations and pH. J Endod 2002;28(7):501-2. [CrossRef]

7. Galler K, Widbiller M, Buchalla W, Eidt A, Hiller KA, Hoffer P, Schmalz G. EDTA conditioning of dentine promotes adhesion, migration and differentiation of dental pulp stem cells. Int Endod J 2016;49(6):581-90. [CrossRef]

8. Calt S, Serper A. Time-dependent effects of EDTA on dentin structures. J Endod 2002;28(1):17-9. [CrossRef]

9. Lee $Y-L$, Lin F-H, Wang W-H, Ritchie H, Lan W-H, Lin C-P. Effects of EDTA on the hydration mechanism of mineral trioxide aggregate. Journal of dental research 2007;86(6):534-8. [CrossRef]

10. Ballal NV, Kandian S, Mala K, Bhat KS, Acharya S. Comparison of the efficacy of maleic acid and ethylenediaminetetraacetic acid in smear layer removal from instrumented human root canal: a scanning electron microscopic study. J Endod 2009;35(11):15736. [CrossRef]

11. Verdelis K, Ellades G, OvllrT, Margelos J. Effect of chelating agents on the molecular composition and extent of decalcification at cervical, middle and apical root dentin locations. Dent Traumatol 1999;15(4):164-70. [CrossRef]

12. Elnaghy A. Effect of QMix irrigant on bond strength of glass fibre posts to root dentine. Int Endod J 2014;47(3):280-9. [CrossRef]

13. Hülsmann $M$, Heckendorff $M$, Lennon $A$. Chelating agents in root canal treatment: mode of action and indications for their use. Int Endod J 2003;36(12):810-30. [CrossRef]

14. Di Lenarda R, Cadenaro M, Sbaizero O. Effectiveness of $1 \mathrm{~mol}$ L1 citric acid and 15\% EDTA irrigation on smear layer removal. Int Endod J 2000;33(1):46-52. [CrossRef]

15. Machado-Silveiro L, González-López S, González-Rodríguez M. Decalcification of root canal dentine by citric acid, EDTA and sodium citrate. Int Endod J 2004;37(6):365-9. [CrossRef]

16. Torabinejad $M$, Parirokh $M$. Mineral trioxide aggregate: a comprehensive literature review-part II: leakage and biocompatibility investigations. J Endod 2010;36(2):190-202. [CrossRef]

17. AlAnezi AZ, Jiang J, Safavi KE, Spangberg LS, Zhu Q. Cytotoxicity evaluation of endosequence root repair material. Oral Surg Oral Med Oral Pathol Oral Radiol Endod 2010;109(3):122-5. [CrossRef]

18. Banchs F, Trope M. Revascularization of immature permanent teeth with apical periodontitis: new treatment protocol? J Endod 2004;30(4):196-200. [CrossRef]

19. Nagas E, Cehreli ZC, Durmaz V, Vallittu PK, Lassila LV. Regional push-out bond strength and coronal microleakage of Resilon after different light-curing methods. J Endod 2007;33(12):14648. [CrossRef]
20. Saghiri MA, Garcia-Godoy F, Gutmann JL, Lotfi M, Asatourian A, Ahmadi H. Push-out bond strength of a nano-modified mineral trioxide aggregate. Dent Traumatol 2013;29(4):323-7. [CrossRef]

21. Guneser MB, Akbulut MB, Eldeniz AU. Effect of various endodontic irrigants on the push- out bond strength of biodentine and conventional root perforation repair materials. J Endod 2013;39(3):380-4. [CrossRef]

22. Goracci C, Tavares AU, Fabianelli A, Monticelli F, Raffaelli O, Cardoso PC, Tay F, Ferrari M. The adhesion between fiber posts and root canal walls: comparison between microtensile and push-out bond strength measurements. Eur J Oral Sci 2004;112(4):353-61. [CrossRef]

23. Ballal NV, Kundabala M, Bhat S, Rao N, Rao BS. A comparative in vitro evaluation of cytotoxic effects of EDTA and maleic acid: root canal irrigants. Oral Surg Oral Med Oral Pathol Oral Radiol Endod 2009;108(4):633-8. [CrossRef]

24. Prabhu S, Rahim N, Bhat K, Mathew J. Comparison of removal of endodontic smear layer using $\mathrm{NaOCl}$, EDTA, and different concentrations of maleic acid-A SEM study. Endodontology 2003;15(1):20-5.

25. Ballal NV, Mala K, Bhat KS. Evaluation of the effect of maleic acid and ethylenediaminetetraacetic acid on the microhardness and surface roughness of human root canal dentin. J Endod 2010;36(8):1385-8. [CrossRef]

26. Ulusoy Öi, Görgül G. Effects of different irrigation solutions on root dentine microhardness, smear layer removal and erosion. Aust Dent J 2013;39(2):66-72.

27. Khedmat S, Shokouhinejad N. Comparison of the efficacy of three chelating agents in smear layer removal. J Endod 2008;34(5):599-602. [CrossRef]

28. González-López S, Camejo-Aguilar D, Sanchez-Sanchez P, Bolaos-Carmona V. Effect of CHX on the decalcifying effect of $10 \%$ citric acid, $20 \%$ citric acid, or 17\% EDTA. J Endod 2006;32(8):7814. [CrossRef]

29. Shokouhinejad N, Hoseini A, Gorjestani H, Shamshiri AR. The effect of different irrigation protocols for smear layer removal on bond strength of a new bioceramic sealer. Iran Endod J 2013;8(1):10-3.

30. Shokouhinejad N, Razmi H, Nekoofar MH, Sajadi S, Dummer PM, Khoshkhounejad M. Push-out bond strength of bioceramic materials in a synthetic tissue fluid. J Dent (Tehran) 2013;10(6):540-7.

31. Shokouhinejad N, Yazdi KA, Nekoofar MH, Matmir S, Khoshkhounejad M. Effect of acidic environment on dislocation resistance of endosequence root repair material and mineral trioxide aggregate. J Dent (Tehran) 2014;11(2):161-6. 